\title{
BIOACTIVITY OF Lantana camara L. ESSENTIAL OIL AGAINST Callosobruchus maculatus (FABRICIUS)
}

\author{
Nooshin Zandi-Sohani ${ }^{1 *}$, Mohammad Hojjati², and Ángel A. Carbonell-Barrachina ${ }^{3}$
}

\begin{abstract}
Lantana camara L. is a widespread plant species mostly native to subtropical and tropical regions of the world. In this study, insecticidal and repellent activities of L. camara essential oil were evaluated against Callosobruchus maculatus (Fabricius) (Col: Bruchidae). Analysis of chemical composition by gas chromatography/mass spectrometry (GC/MS) showed high amounts of sesquiterpenes, mainly $\alpha$-humelene $(23.3 \%)$ and cis-caryophyllene $(16.2 \%)$. The results showed that the essential oil of L. camara has strong repellent activity against adults of $C$. maculatus at all tested concentrations. After 2 and 4 h, 97.4 and 100\% repellency was seen at highest concentrations of $0.4 \mu \mathrm{L} \mathrm{cm}^{-2}$, respectively. Moreover, the oil was found to be toxic to adults when applied by fumigation. Responses varied with the gender of insect and exposure time. The $\mathrm{LC}_{50}$ values were 282.7 and $187.9 \mu \mathrm{L} \mathrm{L}^{-1}$ for females and males, respectively. An increase in the exposure time from 3 to $24 \mathrm{~h}$ caused increasing in mortality from 23.6 to $100 \%$ in males and from 14.1 to $97.1 \%$ in females, at highest concentration $\left(1160 \mu \mathrm{L} \mathrm{L}^{-1}\right)$. According to these results, L. camara essential oil may be useful as an alternative for bean protection against $C$. maculatus.
\end{abstract}

Key words: Fumigant, insecticidal activity, bean protection, Lantana camara.

$\mathrm{T}^{\mathrm{n}, \mathrm{s}}$ he genus Lantana (Verbenaceae) is mostly native to subtropical and tropical regions and now occurs in approximately 50 countries in the world. Lantana camara L., commonly known as wild or red sedge, is the most widespread species of this genus and it is very popular as ornamental plant (Ghizalberti, 2000). The plant has been used in many parts of the world to treat a wide variety of disorders. It has been used as folk remedies for cancer and tumors. Fevers, cold, rheumatisms, asthma, and high blood pressure were treated with preparations from this plant (Rose, 1999). Toxic and poisoning properties of $L$. camara have been reported long ago and it has caused illness and even death in livestock and humans (Morton, 1994).

The pulse beetle, Callosobruchus maculatus Fabricus (Col: Bruchidae), is a major pest of economically important leguminous grains, such as cowpeas, lentils, green gram, and black gram (Raja et al., 2000; Park et al., 2003). Chemical pesticides are commonly applied, to prevent damage of this pest but there is urgent need for an

${ }^{1}$ Ramin Agriculture and Natural Resources University, Department of Plant Protection, Mollasani, Ahvaz, Iran.

*Corresponding author (nzandisohani@yahoo.com).

${ }^{2}$ Ramin Agriculture and Natural Resources University, Department of Food Science \& Technology, Mollasani, Ahvaz, Iran.

${ }^{3}$ Universidad Miguel Hernández, Departamento Tecnología Agroalimentaria, Carretera de Beniel, 03312-Orihuela, Alicante, España.

Received: 13 February 2012.

Accepted: 25 June 2012. alternative solution for protection of harvest.

In recent years research is increasing to use plant secondary metabolites, particularly essential oils, as natural pesticides for crop protection and storage, because of their low toxicity to human beings and minimal environmental impact, in contrast to some synthetic pesticides. Some plants have received global attention and their secondary metabolites have been formulated as botanical pesticides in plant protection.

Chemical composition, antibacterial, antifungal properties of L. camara have been studied in previous researches (Deena and Thoppil, 2000; Kruade et al., 2010; Vadlapudi and Naidu, 2010; Saraf et al., 2011; Saikia and Sahoo, 2011). Insecticidal activities of L. camara essential oil have also been reported on Sitophilus spp. (Mohamed and Abdelgaleil, 2008; Zoubiri and Baaliouamer, 2011) and Tribolium castaneum (Coleoptera: Tenebrionidae) (Mohamed and Abdelgaleil, 2008). In this study, the volatile composition, fumigant and repellency activity of essential oil, from Iranian L. camara, have been studied on one of the most economically important storage pest, Callosobruchus maculatus.

\section{MATERIALS AND METHODS}

\section{Plant materials}

Fresh leaves of L. camara were collected during spring 2011 from Ramin Agriculture and Natural Resources University in Khuzestan province, Iran, where this species is sown as ornamental plant. Leaves were subjected to 
hydrodistillation in a Clevenger-type apparatus for $4 \mathrm{~h}$. The collected oil was dried over anhydrous sodium sulfate and stored at $4{ }^{\circ} \mathrm{C}$ until use.

\section{Analysis of the essential oil}

The isolation, identification, and quantification of the essential oil compounds were performed with a gas chromatograph Shimadzu GC-17A (Shimadzu Corporation, Kyoto, Japan) coupled with a Shimadzu mass spectrometer detector GC/MS QP-5050A. Analyses GC/MS were carried out using helium as carrier gas at a flow rate of $0.9 \mathrm{~mL} \mathrm{~min}^{-1}$ in a split ratio of $1: 20$ on DB- 5 column $(30 \mathrm{~m} \times 0.25 \mathrm{~mm}$ i.d., $0.25 \mu \mathrm{m}$ film thickness) and the following temperature program: (a) $80{ }^{\circ} \mathrm{C}$ for $0 \mathrm{~min}$; (b) rate of $3{ }^{\circ} \mathrm{C} \mathrm{min}{ }^{-1}$ from 80 to 250 ${ }^{\circ} \mathrm{C}$; (c) rate of $25{ }^{\circ} \mathrm{C} \mathrm{min}{ }^{-1}$ from 250 to $300{ }^{\circ} \mathrm{C}$ and hold for $5 \mathrm{~min}$. Injector and detector temperatures were 200 and $300{ }^{\circ} \mathrm{C}$, respectively. Essential oil compounds were identified and confirmed by matching their retention times (authentic standards), retention indices (RI), and NIST05 mass spectral library collection (NIST, 2011). Analyses were run in triplicate.

\section{Insect culture}

Cultures of C. maculatus were obtained from our stock culture and reared in the laboratory on cowpea Vigna unguiculata (L.) Walp. in plastic containers at $25 \pm 1{ }^{\circ} \mathrm{C}$, $65 \pm 5 \%$ relative humidity and dark. Experiments were carried out under the same environmental conditions.

\section{Fumigant toxicity}

To assess $\mathrm{LC}_{50}$ and $\mathrm{LC}_{95}$ of $L$. camara essential oil to $C$. maculatus, 20 female and male adults (1-7 d old) were placed in $50 \mathrm{~mL}$ plastic vials with screw caps, separately. Filter papers (Whatman $\mathrm{N}^{\circ} .2$, cut into $1 \mathrm{~cm}$ diameter discs) were impregnated with oils at doses equivalent to provide fumigant concentrations of $100,160,240$, and $300 \mu \mathrm{L} \mathrm{L}^{-1}$ of air for males and 180, 300, 400, and $480 \mu \mathrm{L} \mathrm{L}^{-1}$ air for females. These concentrations were selected after preliminary tests. The discs were attached to the vial caps and caps were screwed tightly on vials. Control insects were kept in the same conditions without any essential oil. Each dose was replicated five times. The number of dead beetles was counted after $24 \mathrm{~h}$ of exposure to the essential oils. The Abbott (1925) formula was used to correct natural mortality in controls. Data obtained from dose response bioassays were subjected to probit analysis (Finney, 1971) to estimate $\mathrm{LC}_{50}$ and $\mathrm{LC}_{95}$ values using SAS software version 6.12 (SAS Institute, 1997).

A bioassay was designed to determine effect of exposure time on adults' mortality. Twenty female and male adults were exposed separately, to concentrations of $300,600,840,1000$, and $1160 \mu \mathrm{L} \mathrm{L}^{-1}$ air of L. camara essential oil in $50 \mathrm{~mL}$ plastic vials, like in the method previously described. Each dose and control was replicated five times. The exposure time for each dose was $3,6,9,12$, and $24 \mathrm{~h}$. The mortality was calculated using Abbott's correction formula for natural mortality in untreated control (Abbott, 1925).

\section{Repellent activity}

Petri dishes of $8 \mathrm{~cm}$ diameter were used to evaluate repellency of L. camara oil, using the choice bioassay system. The bottom of Petri dishes were covered with filter paper, and half of the filter paper was impregnated with $0.5 \mathrm{~mL}$ of acetone and another half were treated with acetonic solutions of different concentrations of essential oil (0.02-0.4 $\left.\mu \mathrm{L} \mathrm{cm}^{-2}\right)$ and dried for 5 min under a fume extractor. Twenty adults of $C$. maculatus were introduced into each Petri dish and the lid was sealed with parafilm. The experiment was replicated five times and the environmental conditions were the same as those described for insect rearing. The number of insects on each half of the filter paper was counted after 2 and 4 $\mathrm{h}$ of exposure. Percentage repellency $(\mathrm{PR})$ values were computed as $\mathrm{PR}=[(\mathrm{NC}-\mathrm{NT}) /(\mathrm{NC}+\mathrm{NT})] \times 100$, where $\mathrm{NC}=$ number of insects in the control area and $\mathrm{NT}=$ number of insects in the treated area (Nerio et al., 2009).

\section{Statistical analysis}

Experimental data were subjected to ANOVA and the Tukey's least significant difference multi-comparison test to determine significant differences among samples. Statistical analyses were carried out using Statgraphics Plus 5.1 software (Manugistics, Rockville, Maryland, USA).

\section{RESULTS AND DISCUSSION}

\section{Chemical compounds of essential oil}

The major constituent of essential oil of L. camara identified by GC-MS analysis were $\alpha$-humelene, ciscaryophyllene, germacrene-D, bicyclogermacrene, aromadendrene, and $\beta$-curcumine. Other important component includes humulene oxide, sabinene, $\alpha$-terpineol, caryophyllene oxide, zingeberene, $\alpha$-pinene, geranyl acetate, and $\beta$-elemene (Table 1). The chemical composition of the essential oil of Iranian L. camara described in this study agreed quite well with those previously reported in the literature; however, there were differences in relative quantities of volatile compounds. Among the main compounds, sabinene (Sefidkon, 2002; Saikia and Sahoo, 2011), germacrene-D (Khan et al., 2002), bicyclogermacrene (Sefidkon, 2002; Saikia and Sahoo, 2011), zingeberene (Kruade et al., 2010) and caryophyllene oxide (Zoubiri and Baaliouamer, 2011) have been reported from essential oils of L. camara leaves in other studies. Differences in quality and quantity of essential oil composition among this study and others may be due to genetic, climate, geographical, and seasonal variations. 
Table 1. Volatile composition of the essential oil from Lantana camara leaves.

\begin{tabular}{lccr}
\hline & \multicolumn{2}{c}{ Retention indices $^{1}$} & \\
\cline { 2 - 3 } Volatile compound & Experimental & Literature $^{2}$ & $(\%)^{2}$ \\
\hline$\alpha$-Pinene & 977 & 940 & 1.04 \\
Sabinene & 1205 & 977 & 2.12 \\
$\alpha$-Terpineol & 1369 & 1200 & 1.83 \\
Geranyl acetate & 1397 & 1372 & 1.03 \\
$\beta$-Elemene & 1425 & 1394 & 1.03 \\
cis-Caryophyllene & 1460 & 1421 & 16.24 \\
$\alpha$-Humelene & 1473 & 1455 & 23.26 \\
Bicyclogermacrene & 1477 & 1486 & 12.54 \\
Aromadenrene & 1484 & 1463 & 7.00 \\
Zingeberene & 1490 & 1485 & 1.11 \\
Germacrene-D & 1504 & 1500 & 13.16 \\
B-Curcumine & 1579 & 1505 & 4.02 \\
Caryophyllene oxide & 1604 & 1604 & 1.78 \\
Humulene oxide & - & - & 2.54 \\
Others compounds & & & 11.28 \\
\hline
\end{tabular}

${ }^{1}$ Retention indices were calculated for a DB-5 column and literature values were obtained from NIST (2011).

${ }^{2}$ Relative percentage obtained from peak area.

\section{Fumigant toxicity}

The essential oil of $L$. camara showed fumigant toxicity to C. maculatus adults (Table 2). However, males ( $\mathrm{LC}_{50}: 187.9$ $\left.\mu \mathrm{LL}^{-1}\right)$ were more susceptible than females $\left(\mathrm{LC}_{50}: 282.7 \mu \mathrm{L}\right.$ $\left.\mathrm{L}^{-1}\right)$. A strong difference in insect mortality was observed as the oil concentration and exposure time were increased (Figure 1) and there was a significant difference in male and female mortality $(\mathrm{df}=1,100 ; \mathrm{F}=549.3 ; p<0.001)$. At the lowest concentration $\left(360 \mu \mathrm{L} \mathrm{L}^{-1}\right), L$. camara oil caused $63.2 \%$ and $55.4 \%$ mortality after $24 \mathrm{~h}$ in males and females, respectively. However, at $1000 \mu \mathrm{L} \mathrm{L}^{-1}, 100 \%$ mortality was observed for males. The mortality of females reached $97.1 \%$ at highest dose $\left(1160 \mu \mathrm{L} \mathrm{L}^{-1}\right)$ after $24 \mathrm{~h}$. These results were similar to those of Zoubiri and Baaliouamer (2011), who showed that mortality of Sitophilus granarius adults increased with increasing concentration of $L$. camara essential oil. The studies of Bouda et al. (2001) revealed that the essential oil of L. camara had potential to control Sitophilus zeamais and a mortality rate of $100 \%$ was recorded for the highest concentration $(0.5 \% \mathrm{v} / \mathrm{w})$. According to Mohamed and Abdelgaleil (2008), L. camara essential oil showed good contact and fumigant insecticidal activity against Sitophilus oryzae and Tribolium castaneum, while the oil was more effective against $S$. oryzae than $T$. castaneum when used as fumigant.

\section{Repellency activity}

The essential oil of L. camara showed significant repellent activity against the adults of $C$. maculatus at

Table 2. Fumigant toxicity of Lantana camara essential oil to Callosobruchus maculatus adults.

\begin{tabular}{|c|c|c|c|c|c|}
\hline & $\mathrm{LC}_{50}$ & $\mathrm{LC}_{95}$ & Slope \pm SE & $\begin{array}{l}\text { Degree } \\
\text { of } \\
\text { freedom }\end{array}$ & $\begin{array}{c}\text { Chi } \\
\text { square } \\
\left(\chi^{2}\right)\end{array}$ \\
\hline & $-\mu \mathrm{L}$ & 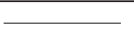 & & & \\
\hline Female & $\begin{array}{c}282.7 \dagger \\
(237.7-323.2)\end{array}$ & $\begin{array}{c}968.9 \\
(684-3716)\end{array}$ & $2.9 \pm 0.54$ & 3 & 26.67 \\
\hline Male & $\begin{array}{c}187.9 \\
(155.7-227.2)\end{array}$ & $\begin{array}{c}933.1 \\
(567-3072)\end{array}$ & $2.2 \pm 0.83$ & 3 & 21.63 \\
\hline
\end{tabular}

${ }^{\dagger}$ Mean (minimum-maximum); SE: Standard error; LC: Lethal concentration.
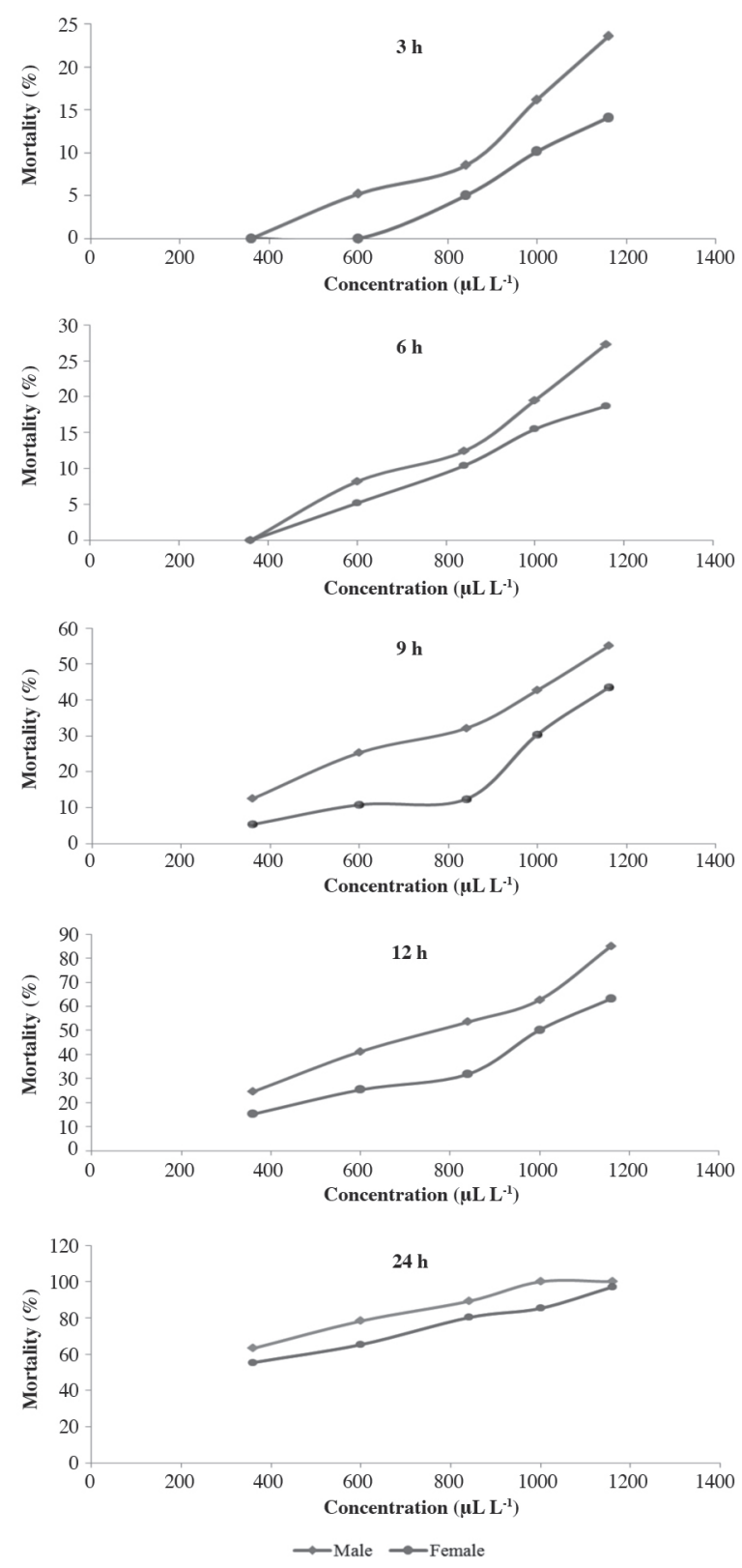

Figure 1. Mortality percentage of adults of Callosobruchus maculatus at various concentrations of Lantana camara essential oil and different exposure times.

all concentrations. Generally, repellency increased when concentrations increased. Furthermore, the repellent activity was increased when insects were exposed for a longer time (Table 3). Complete repellency was only observed when the highest concentration $\left(0.4 \mu \mathrm{L} \mathrm{cm}{ }^{-2}\right)$ was applied for $4 \mathrm{~h}$. To the best of our knowledge, no study has previously been reported on the repellency activity of L. camara against stored product pests; however, essential oils from other plants have been previously evaluated for their repellent activity against Acanthoscelides obtectus (Papachristos and Stamopoulos, 2002), S. oryzae and 
Table 3. Repellent activity of essential oil from Lantana camara leaves against Callosobruchus maculatus at different exposure times.

\begin{tabular}{|c|c|c|}
\hline \multirow[b]{2}{*}{ Dose } & \multicolumn{2}{|c|}{ Repellency \pm SE } \\
\hline & $2 \mathrm{~h}$ & $4 \mathrm{~h}$ \\
\hline$\mu \mathrm{L} \mathrm{cm}{ }^{-2}$ & 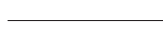 & 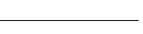 \\
\hline 0.02 & $16.74 \pm 4.55 \mathrm{a}^{\dagger}$ & $18.35 \pm 6.78 \mathrm{a}$ \\
\hline 0.04 & $31.75 \pm 9.53 b$ & $44.87 \pm 5.67 b$ \\
\hline 0.08 & $47.43 \pm 6.45 c$ & $57.43 \pm 4.35 b$ \\
\hline 0.12 & $59.65 \pm 7.43 \mathrm{~cd}$ & $69.98 \pm 6.32 c$ \\
\hline 0.16 & $65.44 \pm 3.98 \mathrm{~d}$ & $87.54 \pm 3.35 \mathrm{~d}$ \\
\hline 0.20 & $87.21 \pm 6.87 \mathrm{de}$ & $95.98 \pm 8.57 \mathrm{e}$ \\
\hline 0.40 & $97.43 \pm 5.09 \mathrm{e}$ & $100 \pm 7.56 \mathrm{e}$ \\
\hline
\end{tabular}

Values followed by the same letter, within the same column, are not significantly different according to Tukey's multiple-range test $(\mathrm{p}<0.005)$

SE: Standard error

Bruchus rufimanus (Liu et al., 2006), Callosobruchus maculatus (Tripathi et al., 2009) and T. castaneum (Tripathi et al., 2009; Zapata and Smagghe, 2010). In all of mentioned studies, essential oils showed considerable repellent activity on insects.

\section{CONCLUSIONS}

The results of this study indicate a high content of sesquiterpenes mainly: $\alpha$-humelene, cis-caryophyllene, germacrene-D, and bicyclogermacrene in L. camara essential oil. These components may be involved in the repellent and insecticide activities of L. camara oil against $C$. maculatus. However, it is difficult to positively correlate the insecticide effect of an essential oil to one or a few active compounds. This study demonstrated the potential of $L$. camara essential oil as repellent and insecticide. Since this species is a common ornamental plant in the South of Iran, it can be used for bean protection against the attack of infesting beetles like $C$. maculatus. The use of plant essential oils will have to be advised for their safety to the environment and consumers. Further research is necessary on the influence of essential oil residue on acceptability of stored products for users.

\section{ACKNOWLEDGEMENT}

The authors wish to thank Ramin Agriculture and Natural Resources University for financial support (Grant $\mathrm{N}^{\circ}$ 901.4).

Bioactividad de aceite esencial de Lantana camara $\mathrm{L}$. contra Callosobruchus maculatus (Fabricius). Lantana camara L. es una especie vegetal nativa de las regiones subtropicales y tropicales del mundo. En este estudio se evaluaron las actividades insecticida y repelente del aceite esencial de L. camara contra Callosobruchus maculatus (Fabricius). El análisis de la composición volátil de este aceite esencial mediante cromatografía de gas/ espectrometría de masa (GC/MS) demostró la presencia de elevadas cantidades de sesquiterpenos, principalmente $\alpha$-humuleno (23.3\%) y cis-cariofileno (16.2\%). Los resultados obtenidos demostraron que el aceite esencial de L. camara tiene una elevada actividad repelente contra los adultos de $C$. maculatus a todas las concentraciones ensayadas. Después de 2 y 4 h la concentración de 0.4 $\mu \mathrm{L} \mathrm{cm}^{-2}$ causó $97,4 \%$ y $100 \%$ de actividad repelente, respectivamente. Además, este aceite esencial fue tóxico para los adultos cuando se aplicó mediante fumigación. Las respuestas a este tratamiento dependieron del sexo del insecto y del tiempo de exposición. Los valores de $\mathrm{LC}_{50}$ fueron 282,7 y $187,9 \mu \mathrm{L} \mathrm{L}^{-1}$ para hembras y machos, respectivamente. Un incremento del tiempo de exposición desde 3 a 24 h causó un aumento de la mortalidad de $23,6 \%$ a $100 \%$ en machos y desde $14,1 \%$ a $97,1 \%$ en hembras, a la mayor concentración ensayada $(1160 \mu \mathrm{L}$ $\left.\mathrm{L}^{-1}\right)$. De acuerdo a estos resultados, podemos concluir que el aceite esencial de L. camara puede ser una alternativa útil en la protección de legumbres contra los ataques de C. maculatus

Palabras clave: fumigantes, actividad insecticida, protección de legumbres, Lantana camara.

\section{LITERATURE CITED}

Abbott, W.W. 1925. A method for computing the effectiveness of an insecticide. Journal of Economic Entomology 18:265-267.

Bouda, H., L.A. Tapondjou, D.A. Fontem, and M.Y.D. Gumedzo. 2001. Effect of essential oil from leaves of Ageratum conyzoides, Lantana camara and Chromolaena odorata on the mortality of Sitophilus zeamais (Coleoptera: Curculionidae). Journal of Stored Products Research 37:103-109.

Deena, M.J., and J. E. Thoppil. 2000. Antimicrobial activity of the essential oil of Lantana camara. Fitoterapia 71: 453-455.

Finney, D.J. 1971. Probit analysis. $3^{\text {rd }}$ ed. Cambridge University Press, New York, USA.

Ghizalberti, E.L. 2000. Lantana camara L. (Verbenaceae). Fitoterapia 71:467-486

Khan, M., S.K. Sivastava, K.V. Syamasundar, M. Singh, and A.A. Naqvi. 2002. Chemical composition of leaf and flower essential oil of Lantana camara from India. Flavour and Fragrance Journal 17:75-77.

Kruade, N.P., V. Jeitak, V.K. Kaul, and O.P. Sharma. 2010. Chemical composition and antibacterial activity of essential oils of Lantana camara, Ageratum houstonianum and Eupatorium adenophorum. Pharmaceutical Biology 48:539-544.

Liu, C.H., A.K. Mishra, R.X. Tan, C. Tang, H. Yang, and Y.F. Shen. 2006. Repellent and insecticidal activities of essential oil from Artemisia princeps and Cinnamomum camphora and their effect on seed germination of wheat and broad bean. Bioresource Technology 97:1969-1973.

Mohamed, M.I.E., and S.A.M. Abdelgaleil. 2008. Chemical composition and insecticidal potential of essential oils from Egyptian plants against Sitophilus oryzae (L.) (Coleoptera: Curculionidae) and Tribolium castaneum (Herbst) (Coleoptera: Tenebrionidae). Applied Entomology and Zoology 43:599-607.

Morton, J.F. 1994. Lantana, or red sedge (Lantana camara L. [Verbenaceae]), notorious weed and popular garden flower; some cases of poisoning in Florida. Economic Botany 48:259-270.

Nerio, L., J. Olivero-Verbel, and E. Stashenko. 2009. Repellency activity of essential oils from seven aromatic plants grown in Colombia against Sitophilus zeamais Motschulsky (Coleoptera). Journal of Stored Product Research 45: 212-214

NIST. 2011. Search for species data by chemical name. National Institute of Standards and Technology (NIST), Gaithersburg, Maryland, USA. Available at http://webbook.nist.gov/chemistry/ name-ser.html (accessed November 2011). 
Papachristos, D.P., and D.C. Stamopoulos. 2002. Repellent, toxic and reproduction inhibitory effects of essential oil vapours on Acanthoscelides obtectus (Say) (Coleoptera: Bruchidae). Journal of Stored Product Research 38:117-128.

Park, C., S.I. Kim, and Y.J. Ahn. 2003. Insecticide activity of asarones identified in Acorus gramineus rhizome against three coleopteran stored-product insects. Journal of Stored Product Research 39:333-342.

Raja, N., S. Albert, A. Babu, S. Ignacimuthu, and S. Dorn. 2000. Role of botanical protectants and larval parasitoid Dinarmus vagabundus (Timberlake) (Hymenoptera: Pteromalidae) against Callosobruchus maculatus Fab. (Coleoptera: Bruchidae) infesting cowpea seeds. Malaysian Applied Biology 29:55-60.

Rose, I.A. 1999. Medicinal plants of the world. Chemical constituents, traditional and modern medical uses. 487 p. Humana Press, Totowa, New Jersey, USA.

Saikia, A.K., and R.K. Sahoo. 2011. Chemical composition and antibacterial activity of essential oil of Lantana camara L. Middle-East Journal of Scientific Research 8:599-602.

Saraf, A., S. Quereshi, K. Sharma, and N.A. Khan. 2011. Antimicrobial activity of Lantana camara L. Journal of Experimental Sciences 2:50-54.
SAS Institute. 1997. SAS/STAT software: changes and enhancements through release 6.12. SAS Institute, Cary, North Carolina, USA

Sefidkon, F. 2002. Essential oil of Lantana camara L. occurring in Iran. Flavour and Fragrance Journal 17:78-80.

Tripathi, A., A. Singh, and S. Upadhyay. 2009. Contact and fumigant toxicity of some common spices against the storage insects Callosobruchus maculatus (Coleoptera: Bruchidae) and Tribolium castaneum (Coleoptera:Tenebrionidae). International Journal of Tropical Insect Science 29:151-157.

Vadlapudi, V., and K.C. Naidu. 2010. In-vitro bioactivity of Indian medicinal plants Lantana camara and Mimosa pudica against important pathogens. Annals of Biological Research 1:98-101.

Zapata, N., and G. Smagghe. 2010. Repellency and toxicity of essential oils from the leaves and bark of Laurelia sempervirens and Drimys winteri against Tribolium castaneum. Industrial Crops and Products 32:405-410.

Zoubiri, S., and A. Baaliouamer. 2011. GC and GC/MS analyses of the Algerian Lantana camara leaf essential oil: Effect against Sitophilus granarius adults. Journal of Saudi Chemical Society doi:10.1016/j.jscs.2011.01.013. 